\title{
A STUDY ON THE INFLUENCE OF MINING FACE ADVANCE RATE ON THE RISK OF ROCKBURSTS AND DEFORMATION OF A ROCK MASS AND A LAND SURFACE \\ Krzysztof TOMICZEK ${ }^{1}$
}

Ph.D. Eng. Krzysztof Tomiczek, Department of Geomechanics and Underground Building, Faculty of Mining, Safety Engineering and Industrial Automation, Silesian University of Technology, Gliwice,

Poland

\section{Summary}

The problem of the influence of face advance rate (FAR) on rockburst threats, or more precisely the question of what its rate's value should be, to make it as low as possible, is very controversial. There are various hypotheses about the influence of FAR on rockburst and tremors, they are sometimes contradictory. A similar problem occurs as of the influence of FAR on rock mass and land surface deformations. The chapter presents selected examples of opinions of Polish researchers and the results of numerical modelling for the influence of FAR on deformations of the rock mass and land surface.

Keywords: rock mass stability, face advance rate, influence of face advance rate, tremors, rockbursts, deformations, land surface subsidence

\section{Introduction}

As a part of the ongoing discussions being kept since the1950s on the influence of face advance rate (FAR) on the occurrence of tremors and rockbursts, the opinion of Professor Sałustowicz (1955) deserves attention. Sałustowicz presented the influence of FAR as a function of a certain critical rate. He wrote: "by increasing the face advance rate, we increase dynamic stress, and thus also the rate of bed deformation and tendency to rockbursts; at the same time, however, we reduce the deformations and the elastic stress. At a certain limiting rate, the static stress decreases to the value of the bed strength, and still below this value, thus the rock bursts disappear."

At the same time, subsidence, bending, cracks and/or landslides may occur on the land surface under the mining. The rock mass deformations arising in the immediate vicinity of the longwall and cover

\footnotetext{
${ }^{1}$ Krzysztof.Tomiczek@polsl.pl, k.tomiczek@yahoo.co.uk , https://orcid.org/0000-0001-9227-310X Researchgate: Krzysztof_Tomiczek
} 
ever higher layers of the rock mass and propagate to the ground surface. There are two types of deformation: continuous deformation and discontinuous deformation. Continuous deformations, which occur most often, are of fundamental importance due to the wide range of occurrence. They are described by means of characteristic quantities called deformation coefficients. Discontinuous deformations are much less common, but are more damaging. They occur, i.e., in the form of thresholds, funnels, sinkholes and gaps.

The time of occurrence of mining influences depends on many factors: depth of mining, strength and rheological properties of rocks, method of roof control, volume of exploited rocks and face advance rate.

Despite many years of research, no clear answer has been found so far, neither on the influence of face advance rate (FAR) on the intensity of underground earth tremors and rockbursts, nor on the influence of FAR on the rock masses and land surfaces deformations.

\section{Selected opinions on the influence of face advance rate on the intensity of underground earth tremors and rockbursts}

\subsection{Views of some researchers}

In general, theoretical considerations and practical experience indicate that as the face advance rate (FAR) increases, the emission of seismic energy increases, and the induced underground earth tremors have higher energy. The relationship found is not linear but rather exponential. It causes that the influence of FAR on the rockburst threat is more pronounced at higher face advance rates (FAR). According to Professor Sałustowicz (1955 and later), bump mines should make slow rate to allow the rock mass for unstressing.

As the velocity of rock deformation increases, so does their strength. Research conducted by Griggs and Handin (1960) and later by other researchers showed that the immediate rock strength is higher than the so-called temporary remained strength. Over time, the strength of the rock decreases.

Wasilewski (1991) stated that the pressure manifestations in the vicinity of the longwall face increase with increasing face advance rate (FAR) and the value of pressure depends on the FAR. He recommends conducting technological tests in the mine in this scope. These considerations concern the rate of longwall face below the socalled critical rate. As long as the longwall face rate in beds of being 
endangered by rockbursts is up to about $80 \mathrm{~m}$ per month (i.e. about $2.7 \mathrm{~m} /$ day), the critical rate mentioned above is not yet achieved and one must always expect a rockbursts. It is determined by the natural properties of the bed, secondary stresses caused by previous exploitations and stresses caused by the longwall face.

The coefficient of the influence of the face advance rate, thus conditioned, can be investigated only individually for each bed and for each mine.

An increase in the face advance rate causes an increase in the deformation rate, consequently also in rock strength. Consequently, rock damage occurs at higher stress levels.

With the face advance rate increasing rapidly, the strength of the rocks increases and the damage becomes more brittle (see Kłeczek, e.g. 2006). As the face advance rate increases, the amount of seismic energy released by the rocks increases.

The hypotheses assuming that faster rate is more advantage were recognized. For example, Professor Biliński (e.g. 1984) considered as the most dangerous the rate should be pointed from the range of 1.1 to $2.6 \mathrm{~m} /$ day.

The analysis of the experimental material carried out by Biliński for five different regions and mines showed that also the length of the longwall for different face advance rate (FAR) significantly determines the hazard of underground tremors.

The smallest tremors occur in longwalls less than $120 \mathrm{~m}$ and in longwalls over $300 \mathrm{~m}$. This is probably related to the load-spanning capacity of the roof, thickness of roof layers, strong rock layers and the ratio of the length of the wall to these spans.

The smallest tremors occurred at face advance rates below of $1 \mathrm{~m} /$ day and at rates of about $3 \mathrm{~m} /$ day.

There may be a significant increase of hazard in the intermediate rate range. The relationship between the average FAR and the state of rockburst hazard in the rock mass disturbed by exploitation is shown in Fig. 2.1; the most dangerous FAR is the rate within $1.3<v<2.2$ $\mathrm{m} / \mathrm{day}$. 


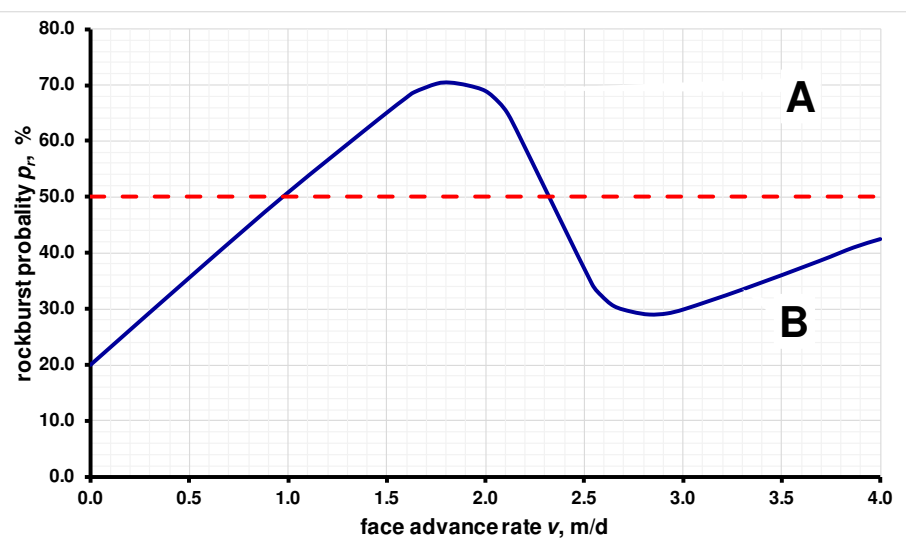

Fig. 2.1. The relationship between the average face advance rate (FAR) $v$ and the state of tremor hazard in the rock mass affected by exploitation according to Biliński. A - I and II degree of rock mass stiffening, B - III and IV degree of rock mass stiffening

Biliński considers two rates of face advance (FAR), i.e. up to $1 \mathrm{~m}$ per day or above $3 \mathrm{~m} /$ day, due to rockburst hazards. Other studies show that for all geological and mining conditions, the face advance rate at which the lowest seismic energy is emitted can be determined. Higher energy is generated both above and below this rate. This rule is often impossible to define for a specific longwall. Most often the rule is not confirmed anymore for the neighbouring longwall, carried out in analogous conditions.

Filcek, Kłeczek and Zorychta (1984) analysed strength and deformation characteristics obtained in the rigid hydraulic compression machine. They concluded that there are critical load rates at which total energy has local extremes. These studies relate to the change in the state of stress in the roof due to the variable face advance rate (FAR). At the same time, the authors stipulate that despite the existence of a relationship between the value of total energy accumulated in the rock sample and the degree of rockburst hazard, it is inadvisable to transfer the obtained quantitative results to practice. There is a proportionality between FAR and the rate of loading the bed, but quantitatively the relationship between these quantities is still unknown.

Goszcz (2004) solved the problem of the face advance rate (FAR) theoretically based on the Budryk-Knothe theory and the relationship between the released seismic energy and the gradient of the subsid- 
ence rate. The results obtained by Goszcz indicate that the ratio of seismic (total) energy released at two different face advance rates is as much as the squares of the face advance rate. This relationship obtained by adequate boundary conditions and simplifications, describes the phenomenon in a qualitative way. Unfortunately, the verification of this solution is difficult, because there are few documented examples of mining in identical geological and mining conditions with different face advance rate. In most cases, changing the face advance rate is a slowdown, but the exponential nature of the relationship between seismic energy emissions and the face advance rate, rate reduction gives less effects.

According to Goszcz, the geomechanical interpretation of the problem of the face advance rate influencing on seismic energy depends on the rock damage mechanics. Part of the deformation in the loaded rock is elastic and the remaining part is resistant, pseudoplastic deformation. The share of energy depends on the rate of increase of deformation. The faster the deformation (the derivative of deformation in time) is, the greater share of elastic deformation. As a result, with a rapidly increasing load, the deformation of the rock is more elastic and ends with its brittle damage. Mining tremors are the result of brittle rock cracking.

Drzewiecki (2004) conducted research on the influence of face advance rate (FAR) on seismic hazard during the first longwall. He stated that this influence could be even greater when was a second longwall. The range of mining influences as a kinematic parameter of the range of main influences increases. "Disturbance of equilibrium in unstable zones, resulting tremors and rockbursts, may occur in such conditions even at a greater distance from the longwall front than at slow face advance rate, and due to the increase in rock strength, the energy of these tremors may be greater." According to Drzewiecki, a change in the face advance rate, resulting in a change in the range of the active volume of the rock mass and a decrease of rate, reduces the intensity of recorded seismic phenomena.

The Interministerial Institute of Geophysics AGH University of Science and Technology in Cracow researched the relationship between the energy emitted from rocks under different face advance rate. On the basis of over 17,000 mining tremors (with energy greater 
than $10^{3} \mathrm{~J}$ ), recorded by the mines in Bytom's Basin, at different face advance rate, using a statistical calculation, it was determined that:

- there is a clear correlation between face advance rate and the number of low-energy mining tremors; with increasing rate - the number of tremors increases,

- due to the poor material for researching, no relationship was found between the face advance rate and the occurrence of high energy tremors. Generally, the research indicated the adverse influence of high face advance rate on the rockburst hazard.

Research in the area of the $51 \mathrm{Z}$ seam section of the "K" mine has shown that as the expansion of mining operations, there is a marked increase in seismic energy activity and tremors. It was found that under normal longwall progress, the zone of maximum energy release and seismic activity displaces deeper into abandoned workings.

In "W" mine in conditions of high rockburst hazard, sectors of longwall in the "clean field" were used primarily for the analysis.

Observations and measurements showed that the caving longwall occurs the phenomenon of side wall unload. This displaces the maximum compressive stress deep into the coal bed and tensile stress - in abandoned workings. This is due to the roof breaking. It should be concluded that the grouping of tremors on the coal field and in abandoned workings have a different character, which depends on the type of stress.

Opinions on the recommended face advance rate vary. It is not uncommon to find opinions about the existence of an optimal rate range $v_{\min } \leq v_{0} \leq v_{\max }$, for which the rockburst hazard is lowest.

It is also believed that due to the lower hazard of rockbursts, caving longwall systems are safer than filling systems. This is confirmed by the statistics of rockburst occurrences in coal mines, while the statistics of the seismic activity of the rock mass in copper mines contradicts it. It also seems that due to the smaller deformations of the rock mass during filling operation there are objective conditions for limiting seismic emissions and rockburst hazards. At the same time, however, due to the lower technical level of the filling longwall equipment and the difficulties of full and continuous roof support, in these conditions even a small dynamics event can run to catastrophic effects in the form of rockbursts. Therefore, regardless of the objective causes of rockbursts, at the current stage of development of the 
mining technique, caving systems should be considered safer because of the rockbursts than filling systems.

Generally, in practice in conditions of high rock burst hazard, as a rule, the face advance rate and longwall heading progress is limited. In beds included in the 1st degree rockburst hazard it is not necessary to limit the face advance rate, and it is even possible to increase it.

However, current research and practice do not provide an unequivocal answer to this problem.

\subsection{Opinions of experts-practitioners}

Polish experts-practitioners (Konopko et al., 1995) presented their experience on the face advance rate (FAR) and the height of selecting thick beds stratified in layers (Figs 1.2 and 1.3, Tab. 2.1).

Table 2.1

Opinions of expert-practitioners on the face advance rate (after Konopko et al., 1995)

\begin{tabular}{c|c|c|c}
\hline \multirow{2}{*}{ Problem } & $\begin{array}{c}\text { Type of } \\
\text { longwalls }\end{array}$ & Hazards & $\begin{array}{c}\text { Recommended } \\
\text { rate }\end{array}$ \\
\hline \multirow{2}{*}{$\begin{array}{c}\text { Face advance rate } \\
\text { of caving longwalls }\end{array}$} & Initial & Lower & $3.0 \mathrm{~m} /$ day \\
\cline { 2 - 4 } & Following & Higher & - \\
\cline { 2 - 4 } $\begin{array}{c}\text { Face advance rate } \\
\text { of filling longwalls }\end{array}$ & Final & Highest & $2.3 \mathrm{~m} /$ day \\
\cline { 2 - 4 } & Following & Lower & $2.3 \mathrm{~m} /$ day \\
\hline $\begin{array}{c}\text { Degree of rockburst } \\
\text { hazard }\end{array}$ & Final & Highest & $2.4-2.6 \mathrm{~m} /$ day \\
\hline $\begin{array}{c}\text { Optimal face ad- } \\
\text { vance rate }\end{array}$ & $\begin{array}{c}\text { No limitations } \\
\text { or }>3.6 \mathrm{~m} / \text { day }\end{array}$ & IInd & IIIrd \\
\hline
\end{tabular}

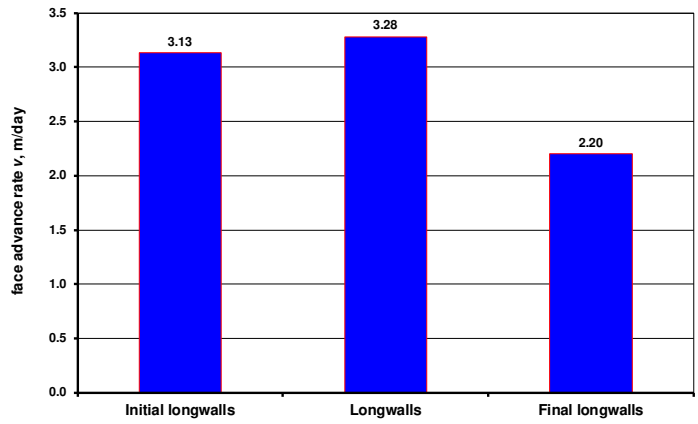

Fig. 2.2. Preferred progress for initial, following and final caving longwalls according to expert-practitioners (after Konopko et al., 1995) 


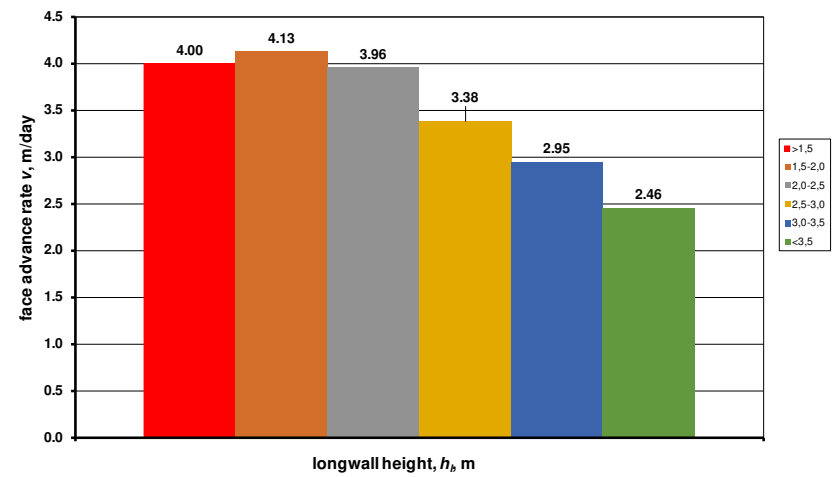

Fig. 2.3. The preferred face advance rate $v$ of caving longwalls of various face heights $h$ according to experts, assuming a stratification in layers of $h_{l}=2.76-2.00 \mathrm{~m}$ (after Konopko et al., 1995)

\section{Mining-inducted deformations of land surface}

The first attempts to measure land surface mining-inducted subsidence were made at the beginning of the 19th century. Further work developed in the field in the 20th century in Poland went in four directions:

- solutions based on empirical formulas; indicator of deformations are determined on the basis of formulas, nomograms, charts - pioneering solutions of J. Gonot, G. Dumont and P. H. Leontowski,

- geometric-integral theories based on axioms of empirical solutions (S. Knothe, Z. Kowalczyk, T. Kochmański, J. Zych, M. Chudek and L. Stefański; see e.g.: Borecki et al., 1980, Chudek, 1980, Knothe, 1984, Zych, 1987),

- research based on continuum models, in which the state of stress and displacement is determined by state equations dependent on the assumed medium model (A. Sałustowicz, J. Litwiniszyn, F. Dymek and H. Gil),

- the theory of the stochastic medium (J. Litwiniszyn, H. Smolarski and J. Mączyński).

3.1. Theoretical basis for calculating mining influence on the land surface and the short characteristics of geometric-integral theories

The rock mass movements resulting from mining are unique determined by the components of displacements $(u, v, w)$ as a functions of the coordinates of the rock mass points $(x, y, z)$ and time $t$ 


$$
\begin{aligned}
& u=u(x, y, z, t) \\
& v=v(x, y, z, t) \\
& w=w(x, y, z, t)
\end{aligned}
$$

The slopes of the mining subsidence $T$ in the directions of the coordinate system axis $(x, y)$ are functions of subsidences $w$ and are

$$
\begin{aligned}
& T_{x}=\frac{\delta w}{\delta x} \\
& T_{y}=\frac{\delta w}{\delta y}
\end{aligned}
$$

Curvatures of the subsiding trough $K$ of continuous deformations

$$
\begin{aligned}
& K_{x} \cong \frac{\delta^{2} w}{\delta x^{2}} \\
& K_{y} \cong \frac{\delta^{2} w}{\delta y^{2}}
\end{aligned}
$$

Vertical strains - derivative of vertical displacements

$$
\varepsilon_{z}=\frac{\delta w}{\delta z}
$$

Horizontal strains

$$
\begin{aligned}
& \varepsilon_{x}=\frac{\delta u}{\delta x} \\
& \varepsilon_{y}=\frac{\delta v}{\delta y}
\end{aligned}
$$

The geometrical-integral theories are based on the principle that the exploitation of an element with the bed volume $\mathrm{d} V$, that projection on the horizontal plane occupies the area $\mathrm{d} P$ results at point $A$ above the roof of bed in the subsidence:

$$
\mathrm{d} w_{A}=a g f(x) \mathrm{d} P
$$

where

$a$ - exploitation coefficient depending on the method of roof control,

$g$ - bed thickness,

$x$ - horizontal distance of point $A$ from the exploited element $d P$, 
$f(x)$ - influence function; different theories using different forms of this function.

Professor Knothe, adopting the Gaussian distribution of influences based on the analysis of subsidence of land surfaces in the Silesian Coal Basin, derived the formula for the influence function $f(x)$

$$
f(x)=\frac{w_{\max }}{r} e^{-\frac{\pi x^{2}}{r^{2}}}
$$

The function corresponds to the slope of the subsidence through profile

$$
T(x)=\frac{d w}{d x}=\frac{w_{\max }}{r} e^{\frac{-\pi x^{2}}{r^{2}}}
$$

and curvature of the subsidence through profile

$$
K(x) \approx \frac{d^{2} W}{d x^{2}}=\frac{2 \pi W_{\max }}{r^{3}} x e^{\frac{-\pi x^{2}}{r^{2}}}
$$

Extreme curvature values occur at a distance of $0.4 r$ from the edge of mining exploitation field and are

$$
K_{\max }= \pm \sqrt{\frac{2 \pi}{e}} \frac{w_{\max }}{r^{2}}= \pm 1.52 \frac{w_{\max }}{r^{2}}
$$

The horizontal displacements of points of the subsidence trough profile are given by the formula

$$
u(x)=\frac{w_{\max }}{\sqrt{2 \pi}} e^{\frac{-\pi x^{2}}{r^{2}}}
$$

wherein $u_{\max }=0,4 w_{\max }$.

Horizontal strains

$$
\varepsilon(x)=\frac{d u}{d x}=-\frac{\sqrt{2 \pi}}{r^{2}} w_{\max } x e^{\frac{-\pi x^{2}}{r^{2}}}
$$

wherein $\varepsilon_{\max }= \pm \frac{w_{\max }}{r} e^{-1,5}= \pm 0,6 \frac{w_{\max }}{r}$.

\subsection{The problem of the influence of face advance rate}

Observations and field measurements show that displacements as a result of mining begin to occur with a certain delay, gradually increase and reach their maximum value after a certain time. 
It was found that the highest subsidence rate usually occurs in the second year after mining. In some mining basins, maximum landsurfacedown rates occur in the first months after mining, while in others basins - after four years (Knothe, 1980).

When determining the expected displacements, the influence of the time was usually taken into account by introducing a time coefficient into the displacement formulas, determining the ratio of the instantaneous subsidence to the maximum final subsidence, depending on the time since mining ending (see e.g. Strzałkowski 2001, Ścigała, 2009.

The time coefficient is also associated with the influence of mining, i.e. the face advance rate (FAR) on the phenomena occurring in the rock mass and on the shape of the subsidence though and the values of land surface deformation coefficients (see e.g. Chudek et al., 2007).

In the 1950 s and 1960s, after making many calculations, Knothe stated that the subsidence rate is proportional to the difference between the final subsidence $w_{k}$, that a point on the land surface may undergo as a result of exploitation a certain part of the bed up to the time moment $t$, in the area of mining influence on this point, and the value of the pointdown in the time $t$

$$
\frac{d w}{d t}=\varnothing\left[w_{k}(t)-w(t)\right]
$$

where

$c$ - proportionality coefficient, for Silesian Coal Basin $c=0.5 /$ year for a predominance of thick and hard sandstones in overlying layers, $\mathrm{c}=7 /$ year if there are brittle and/or plastic rock layers above the bed.

Measurements and calculations carried out by Professor Knothe have determined that the advantageous effect of increasing the face advance rate (FAR) to land surface protection increases with decreasing $c$ coefficient. It is higher for mining areas where the time after which the maximum ground movements are longer, i.e. for the rock mass with thick and hard rock layers. The measurements also allowed the following conclusion: taking into account the depth of mining, the effect of increasing the face advance rate at smaller depths of mining is more advantageous, than when mining operations are at higher depths. 
Based on Knothe's solutions, the problem of land surface deformation over time in Poland, researched: Skinderowicz, Trojanowski, Białek, Drzęźla, Rogowska, Sroka and others.

\section{Numerical model}

\subsection{Geological and mining conditions}

Numerical simulations were carried out on an example of mining of the $35 \mathrm{~B}$ bed in the $\mathrm{S}$ coal mine. The simulation was with caving of the roof layers. Two face advance rate (FAR) were simulated: the first "low" and the second "high", i.e. ten times higher than the "low" rate. Calculations were made based on the Finite Differences Method FLAC2D v. 3.23 code.

It was a continuation of research on the behaviour of the rock mass in the vicinity of mining excavations started in 1992 in the Laboratory of Numerical Modelling of the Rock Mechanics Laboratory at the Department of Geomechanics, Underground Construction and Surface Protection (Silesian University of Technology, Kwaśniewski and Wang, 1994).

The rock mass is made of Quaternary and Carboniferous formations. Coal beds are variable with numerous thinning and outpetering. Slate-silty layers occur in the roof and floor. Sandy shales change into fine-grained sandstones. The dip of layers in the SW direction is $3-7^{\circ}$.

The $35 \mathrm{~B}$ bed lies at a depth of $-465 \mathrm{~m}$ in the north to $-580 \mathrm{~m}$ in the south. The bed has an average thickness of $2.1 \mathrm{~m}$. It is a nonrockbursting bed. In the roof of this bed in the vicinity of the $100 \mathrm{C}$ longwall there are silt and sand shales, and in the floor - too. The mining area of the 35B bed with the $100 \mathrm{C}$ longwall is enclosed by faults: from the north "K" with a throw of $60 \mathrm{~m}$, and from the east "J" with a throw of $30 \mathrm{~m}$. From the south it is limited by the line of the mining area of the $\mathrm{M}$ mine.

The high-efficiency longwall complex 100C equipment consists of:

- mechanized hydraulic support Glinik-13/26 licensed by MECO, equipped with electrohydraulic control,

- Anderson ELECTRA 1000 shearer from Anderson-Longwall, with a maximum mining rate of $9.97 \mathrm{~m} / \mathrm{min}$.,

- MECO longwall conveyor, with a nominal capacity of $1500 \mathrm{t} / \mathrm{h}$,

- MECO chain longwall conveyor, the capacity $1500 \mathrm{t} / \mathrm{h}$,

- MECO 6×420 heading crossing support with extended roof-bars. 
Data characterizing the mining of the $35 \mathrm{~B}$ bed by the longwall 100C:

- method of roof control: roof layers caving,

- longwall length: $300 \mathrm{~m}$,

- longwall stopway: 1,248.8 m,

- date of starting mining 16.01.1993,

- date of finishing mining 31.12.1993,

- longwall height $2.1 \pm 0.2 \mathrm{~m}$,

- face advance rate over a period of 1 month: from 62 to $196 \mathrm{~m} / \mathrm{month}$,

- maximum daily rate $12.5 \mathrm{~m} /$ day,

- average daily rate: $3.57 \mathrm{~m} /$ day.

\subsection{Characteristics of the FLAC2D code}

The FLAC2D code is a finite difference program. It enables the building of numerical rock mass models and simulation of the behaviour of soil and rock both after reaching the point of plasticity (plastic flow) and the ultimate strength (brittle fracture). Due to its properties, FLAC enables solving rock engineering problems, analysis and design of excavations and their supports, underground and groundbased structures. FLAC2D is based on the Lagrangian calculation scheme.

\subsection{Rock mass model}

A 2D, numerical, structural and physical model of the rock mass was built, $2250 \mathrm{~m}$ long and $650 \mathrm{~m}$ thick. The model was divided by "W" and "J" faults into three parts: left - west, middle and right - east.

The based model was built in 1993 for the research work carried out at the Laboratory of Rock Mechanics of DoGUBaLSP as part of ministerial project No. 231/CS6-9/92 entitled "High-efficiency longwall complex and new coal mining technology in the S mine."

Fifty-two rock layers in the roof and twelve layers in the floor of the coal bed lying at the depth of $535.25 \mathrm{~m}$ meters with a thickness of $2.25 \mathrm{~m}$ were distinguished and modelled. The rock mass flat model was divided into 9750 rectangular elements $150(L) \times 65(H)$ with an average length of $15 \mathrm{~m}$ and a width of $10 \mathrm{~m}$, forming a finite difference grid with 9,966 nodes (Fig. 4.1). 


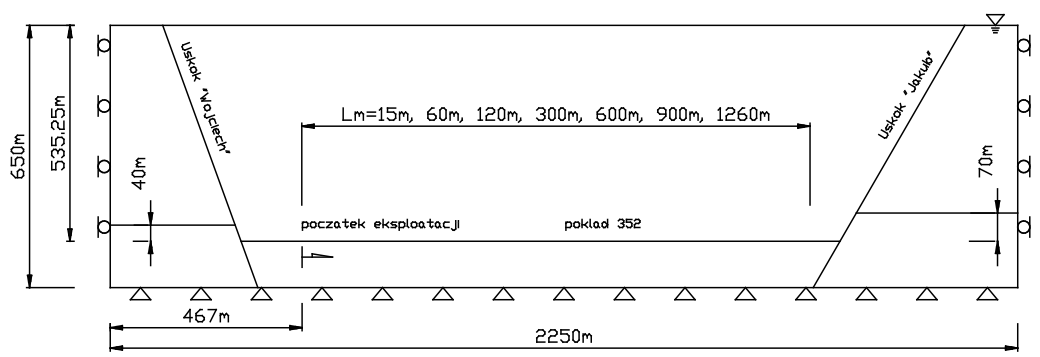

Fig. 4.1. A simplified scheme of the modelled rock mass plate with seven stages $L_{m}$ of $35 \mathrm{~B}$ bed mining

Two large faults - west " $W$ " and east " $J$ " dividing the tested rock mass into three parts, were modelled with the built-in FLAC2D model of the discontinuity between two parts of the finite difference mesh.

The longwall mechanized support was modelled using a 10-units structural element $3.5 \mathrm{~m}$ width and $2.25 \mathrm{~m}$ high.

In order to study the changes in stresses and displacements in the rock mass associated with the mining of the $35 \mathrm{~B}$ bed with the $100 \mathrm{C}$ longwall, the bed mining was simulated in seven stages of $L_{m}=15 \mathrm{~m}$, $60 \mathrm{~m}, 120 \mathrm{~m}, 300 \mathrm{~m}, 600 \mathrm{~m}, 900 \mathrm{~m}$, and $1260 \mathrm{~m}$.

The $35 \mathrm{~B}$ bed was mined with roof layers caving.

Depending on the distance from the longwall face, rocks in the caving zone were assigned different properties, for example values of volume density, bulk and shear modules (Figs 4.2 and 4.3).

Example:

Stage 1 .

$L_{m}=15 \mathrm{~m} \quad L_{c}=0 \mathrm{~m} \quad H_{c}=0 \mathrm{~m}$

$L_{m}$ - the length of the mined part of longwall

$L_{C}$ - range of the caving zone

$H_{c}$ - height of the caving zone

model null $i=32, \quad j=13 \quad y=-535,25 \mathrm{~m}$

Mechanized support:

support $x=479,55 \quad \bmod$ null $i=32 \quad j=13 \quad y=-535,0$ 


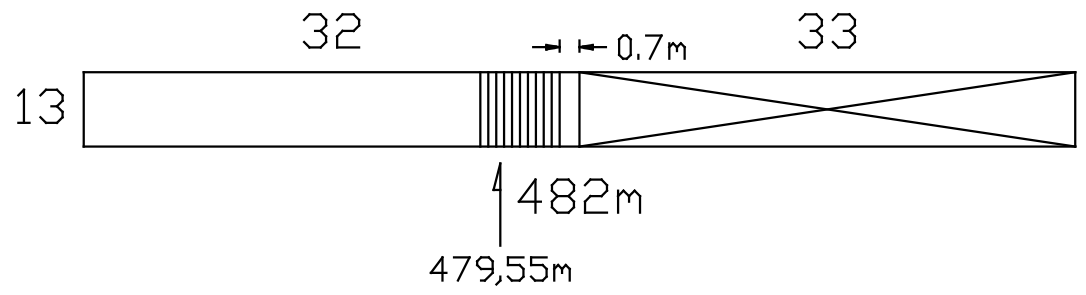

Fig.. 4.2. Simplified scheme of the model of the first stage of mining ( $\left.L_{m}=15 \mathrm{~m}\right)$

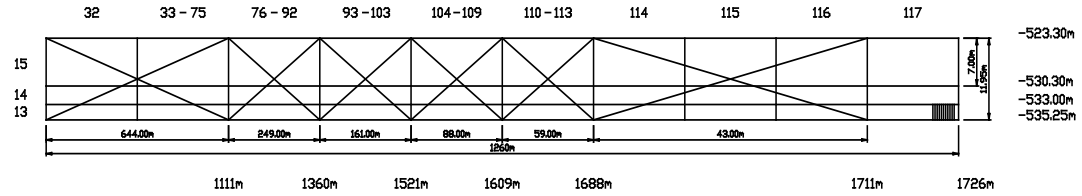

Fig. 4.3. Simplified scheme of the model the seventh stage of mining $\left(L_{m}=1260 \mathrm{~m}\right)$

Simulating the mining at "low" rate, calculations were completed after 13,000 steps, which corresponded to the 350-day mining of the $35 \mathrm{~B}$ bed by a $100 \mathrm{C}$ longwall and an average face advance rate (FAR) of about 3.6m/day. Simulation of mining at "high" rate (10 times higher) was completed after 1,300 steps.

The results of the first attempts to simulate exploitation at different face advance rate can be found in the research of Kwaśniewski and Wang (1994). The development and full analyses of the project are in the MD thesis (Tomiczek, 1995).

\subsection{Behaviour of the rock mass at the end of selected stages of bed mining}

Due to the volume limitations of the chapter, only selected simulation results are presented (Tab.1 and Figs 4.4-4.11). For the same reasons, the results of calculations were not discussed, leaving conclusions to the readers. 
Table 4.1

Values of deformation coefficients in the part between "W" and "J" faults for various stages of $L_{m}$ exploitation and face advances rates (FAR); $L_{f}$ - distance from longwall face, $L_{e}$ - range of mining influences in the right side (end point of mining)

\begin{tabular}{|c|c|c|c|c|c|c|}
\hline \multirow[t]{2}{*}{$\begin{array}{c}\text { Rate/ } \\
\text { distance } \\
\text { from } \\
\text { longwall } \\
\text { face } L_{f}, \mathrm{~m}\end{array}$} & \multirow[t]{2}{*}{$\begin{array}{c}w_{\max } \\
\mathrm{mm} \\
\text { in the part } \\
\text { between } \\
\text { faults }\end{array}$} & \multicolumn{2}{|c|}{$\begin{array}{c}\mathcal{E}_{x m a x} \\
\mathrm{~mm} / \mathrm{m} \\
\text { in the part be- } \\
\text { tween faults } \\
\text { Side }\end{array}$} & \multicolumn{2}{|c|}{$\begin{array}{c}T_{\max } \\
\mathrm{mm} / \mathrm{m} \\
\text { in the part be- } \\
\text { tween faults } \\
\text { Side }\end{array}$} & \multirow[t]{2}{*}{$\begin{array}{l}\text { Range of mining } \\
\text { influences in the } \\
\text { right side (end } \\
\text { point of mining) } \\
L_{e}, \mathrm{~m}\end{array}$} \\
\hline & & Left & Right & Left & Right & \\
\hline \multicolumn{7}{|c|}{ Stopway of longwall $L_{m}=60 \mathrm{~m}$} \\
\hline "low" & -74.90 & -0.168 & 0.242 & -0.376 & 0.590 & - \\
\hline$L_{f}, \mathrm{~m}$ & 100.50 & 724.5 & 490.5 & 705.0 & 471.0 & 1134.0 \\
\hline "high" & -62.30 & -0.168 & 0.200 & -0.245 & 0.521 & - \\
\hline$L_{f}, \mathrm{~m}$ & 393.00 & 724.5 & 490.5 & 276.0 & 471.0 & 527.0 \\
\hline \multicolumn{7}{|c|}{ Stopway of longwall $L_{m}=600 \mathrm{~m}$} \\
\hline "low" & -910.00 & -1.690 & 0.985 & -2.000 & 2.900 & - \\
\hline$L_{f}, \mathrm{~m}$ & -322.50 & -244.5 & 204.0 & -614.5 & 28.0 & 516.0 \\
\hline "high" & -148.80 & -0.245 & 0.284 & -0.363 & 0.558 & - \\
\hline$L_{f}, \mathrm{~m}$ & -439.50 & -615.0 & -49.5 & -556.5 & -49.5 & 535.5 \\
\hline \multicolumn{7}{|c|}{ Stopway of longwall $L_{m}=1260 \mathrm{~m}$} \\
\hline "low" & -1508.00 & -2.058 & 0.558 & -2.684 & 2.300 & - \\
\hline$L_{f}, \mathrm{~m}$ & -747.50 & -630.5 & -396.0 & -1234.5 & -26.0 & - \\
\hline "high" & -486.10 & -0.752 & 0.458 & -1.020 & 1.479 & - \\
\hline$L_{f}, \mathrm{~m}$ & -825.50 & -903.5 & -708.5 & -1235.0 & -630.5 & - \\
\hline
\end{tabular}

Stopway of longwall $L_{m}=1260 \mathrm{~m}$ "high" rate in relation to the time of end of "low" face advance rate (FAR)

\begin{tabular}{c|c|c|c|c|c|c}
\hline "high" & -973.00 & -1.030 & 0.200 & -1.579 & 1.526 & - \\
\hline$L_{f}, \mathrm{~m}$ & -513.50 & -626.0 & -1352.0 & -1234.5 & 12.5 & - \\
\hline
\end{tabular}
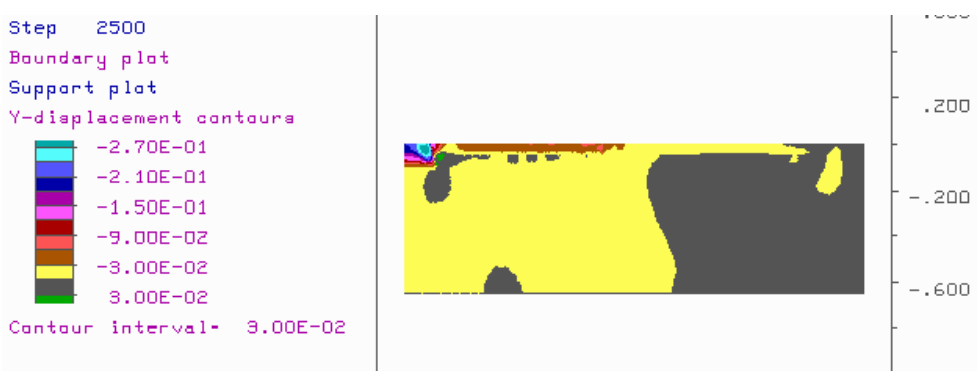


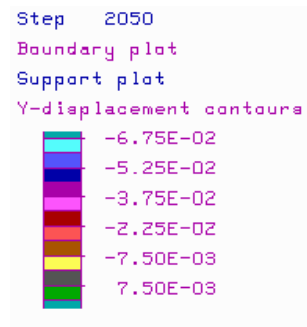

Cantaur interval = 7.50E-03

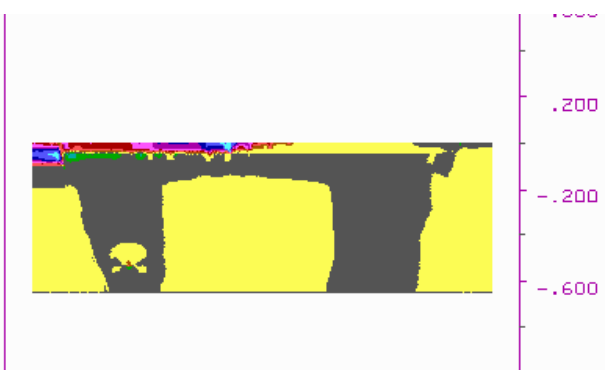

Fig. 4.4. Vertical displacement of the rock mass for "low" (top) and "high" (bottom) face advance rate, in the first $\left(L_{m}=15 \mathrm{~m}\right)$ stage of mining
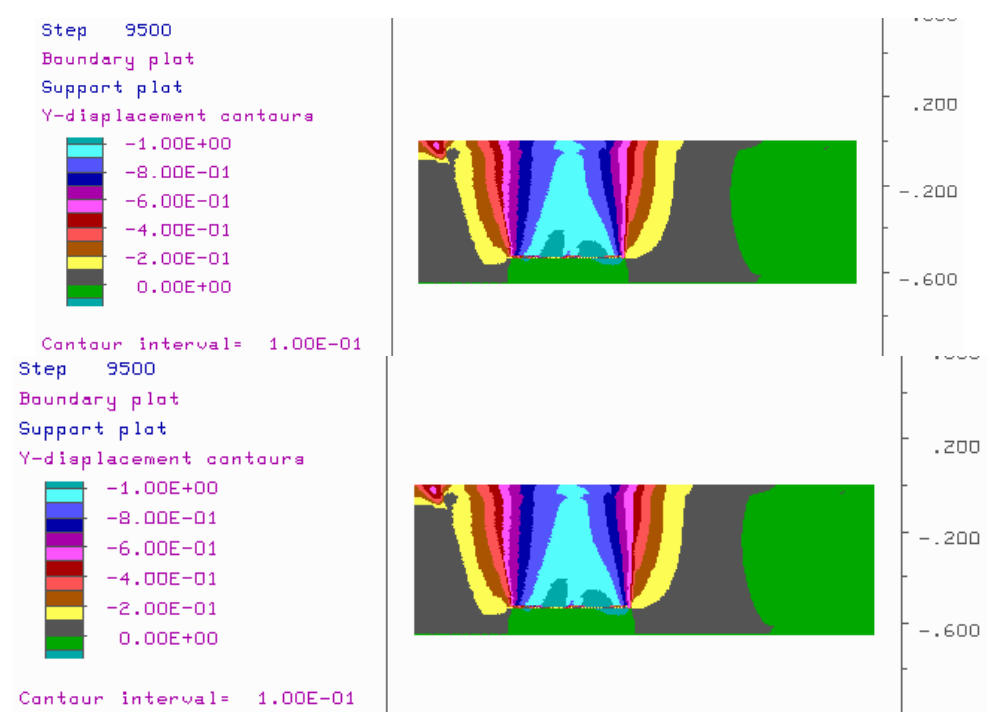

Fig. 4.5. Vertical displacement of the rock mass for "low" (top) and "high" (bottom) face advance rate, in the fifth $\left(L_{m}=600 \mathrm{~m}\right)$ stage of mining
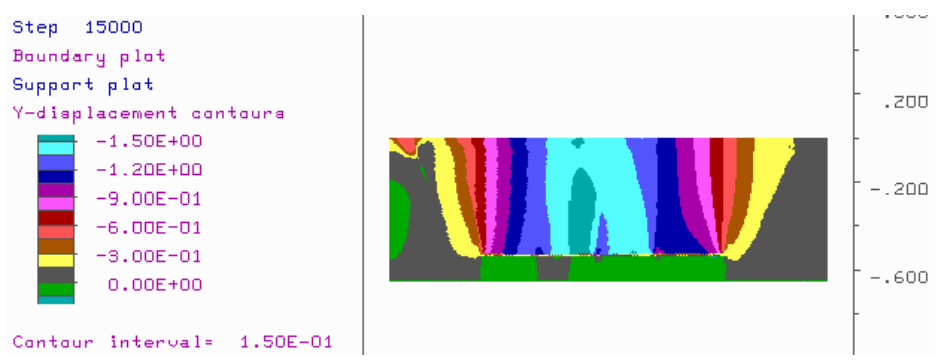


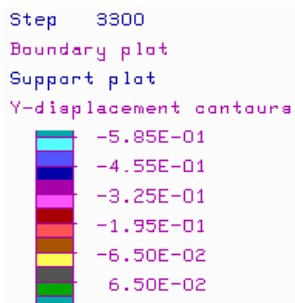

Cantaur interval = 6.50E-02

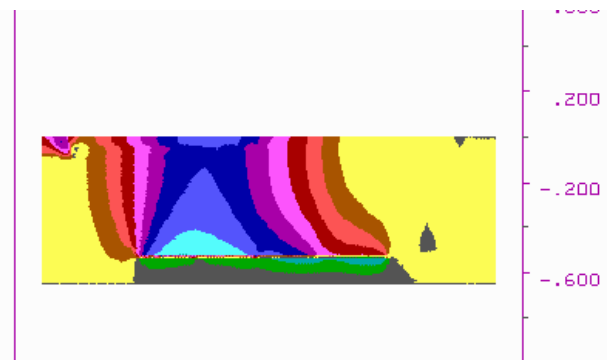

Fig. 4.6. Vertical displacement of the rock mass for "low" (top) and "high" (bottom) face advance rate, in the seventh $\left(L_{m}=1260 \mathrm{~m}\right)$ stage of mining

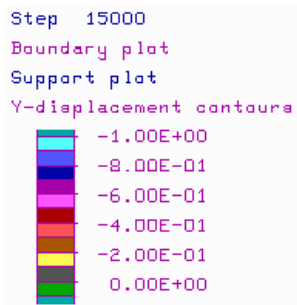

Cantaur interwal = $1.00 \mathrm{E}-01$

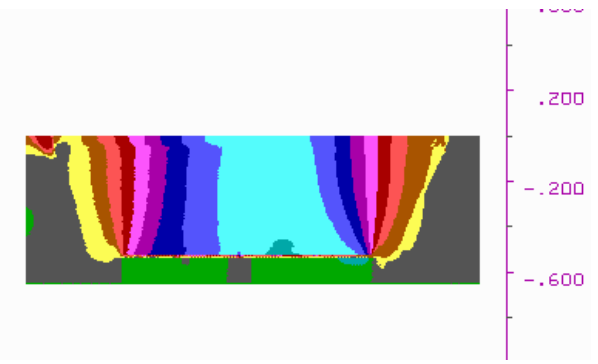

Fig. 4.7. Vertical displacement of the rock mass for "high" face advance rate, in the seventh $\left(L_{m}=1260 \mathrm{~m}\right)$ stage of mining (after a time corresponding to the finish of mining with "low" rate).

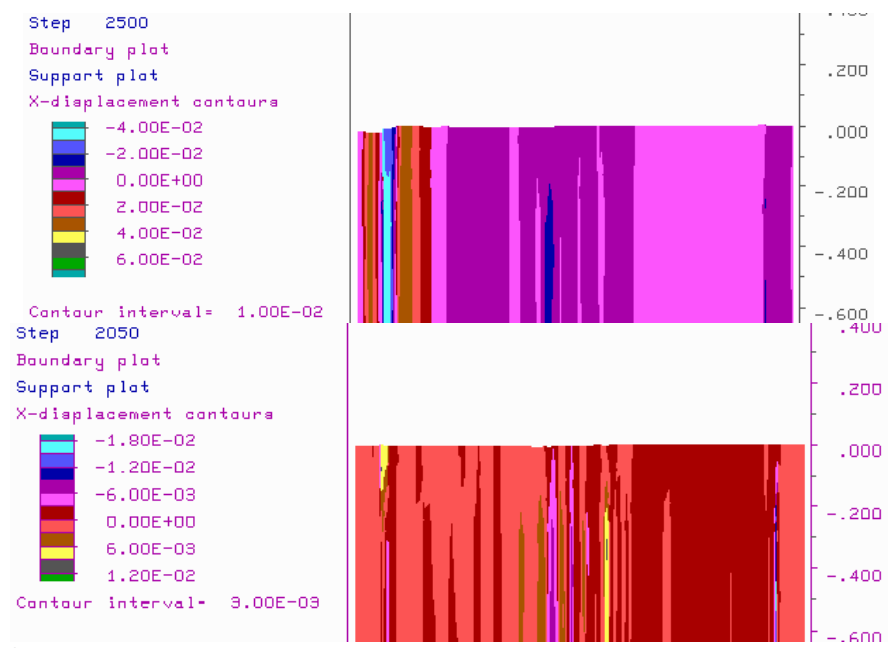

Fig. 4.8. Trough subsidence profile for "low" (top) and "high" (bottom) face advance rate, in the first $\left(L_{m}=15 \mathrm{~m}\right)$ mining stage 


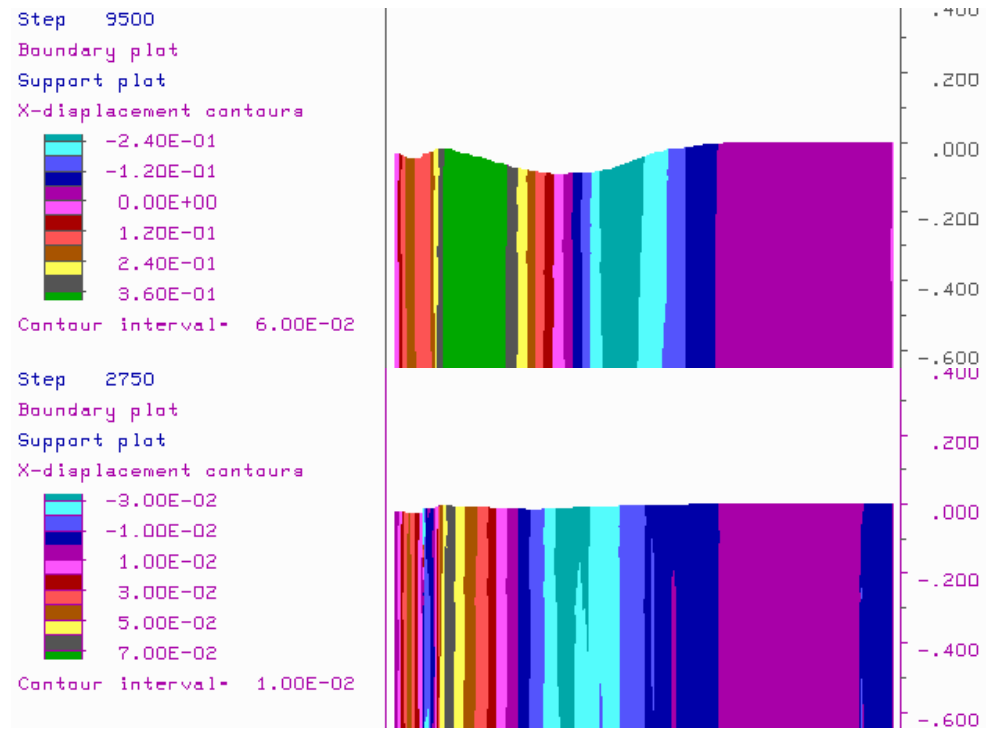

Fig. 4.9. Trough subsidence profile for "low" (top) and "high" (bottom) face advance rate, in the fifth $\left(L_{m}=600 \mathrm{~m}\right)$ mining stage

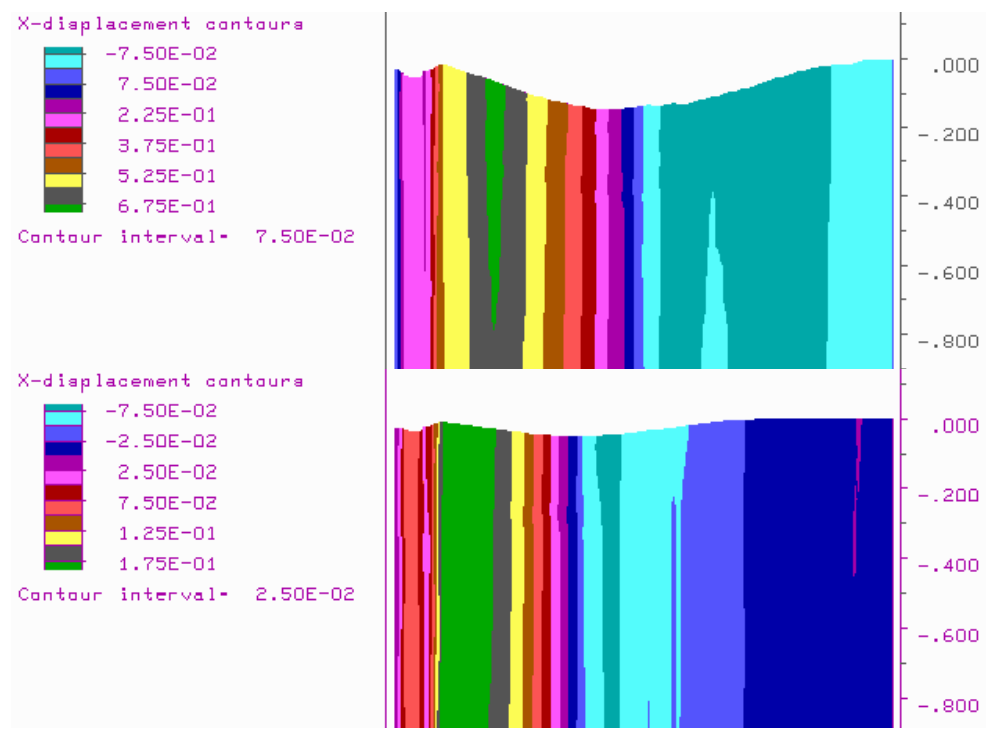

Fig. 4.10. Trough subsidence profile for "low" (top) and "high" (bottom) face advance rate, in the seventh $(L m=1260 \mathrm{~m})$ mining stage. 


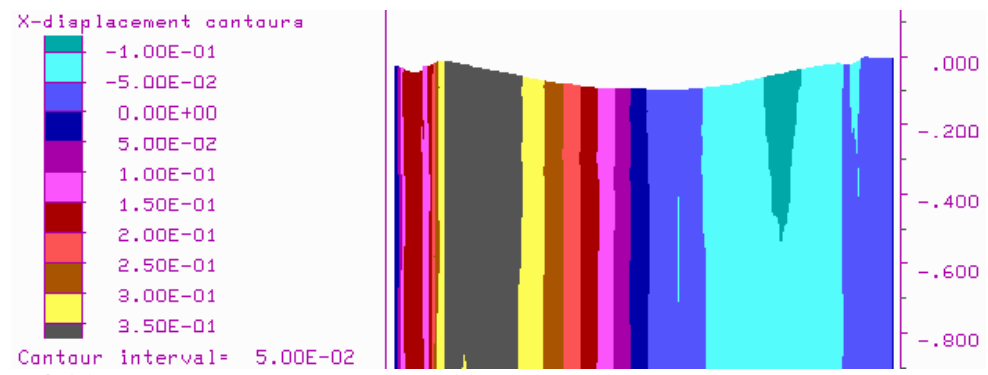

Fig. 4.11. Trough subsidence profile for "high" face advance rate, in the seventh $\left(L_{m}=1260 \mathrm{~m}\right)$ mining stage (after a time corresponding to the finish of mining with "low" rate).

The results of numerical modelling and simulation of the rock mass simulation of coal bed longwall mining allowed to state that increasing the face advance rate leads to a decrease in the values of deformation coefficients and the range of continuous and discontinuous deformation.

In the initial stages of mining, e.g. in the first stage, when the bed was excavated a distance of only $15 \mathrm{~m}\left(L_{m}=15 \mathrm{~m}\right)$, these differences were small. For example, the maximum values of displacement vectors of the supported part of the longwall excavation roof were 1.80 and $2.23 \mathrm{~mm}$ for "high" and "low" rate respectively.

The differences, to the advantage of "high" rate, increased as the longwall stopway growths and became clearly noticeable from the fourth operating stage $\left(L_{m}=300 \mathrm{~m}\right)$.

After finishing the bed mining (seventh stage, $L_{m}=1260 \mathrm{~m}$ ), the maximum displacement vectors in the vicinity of the longwall face, equal to $98.9 \mathrm{~cm}$ in the case of mining at "low" rate, were more than four times larger than those equal to $23.5 \mathrm{~cm}$, corresponding to "fast" face advance rate. The direction and distribution of displacement vectors in the immediate vicinity of the longwall face was different.

For "low" rate, the zone of increased rock mass subsidence is much more regular, symmetrical than that corresponding to "high" face advance rate. The maximum values of land surface subsidence equal to $150.8 \mathrm{~cm}$, are more than three times larger and cover larger land areas; for the "low" rate, the subsidence extended to the entire study area. In the depth of the rock mass, in the rock caving zone above a selected part of the bed, the maximum subsidence was 157.5 
cm when mining at "low" rate. They were about 2.7 times larger than the subsidence resulted the "high" face advance rate. The values of the roof displacement vector in the supported part of the longwall excavation are more than seven times higher.

The damage zone corresponding to the "low" face advance rate occupies almost the entire rock mass between the "J" and "W" faults, while at "high" rate it is limited, except the plasticized soils near the land surface, only to the immediate vicinity of the selected bed.

Equally large differences occur in the maximum values of slopes and horizontal deformations of the land surface. Twice larger, reaching $2.68 \mathrm{~mm} / \mathrm{m}$ when operating at "low" rates are compared to those corresponding to the operation of "fast" face advance rate slope values. Horizontal deformations are also in the west part of basin three times higher.

\section{Summary and final remarks}

The problem of the influence of the time coefficient on the behaviour of the rock mass in the vicinity of longwall excavations has become very important because in-, but not only, coal mines, highefficiency mining complexes are being bright in an increasingly larger scale.

These complexes allow mining exploitation coal beds at rates reaching several meters for a day. Due to the tremors and rock bursts, protection of the land surface, ground and underground structures, it is necessary to study influence of the face advance rate on seismic activity and rock mass deformation.

The chapter presents selected results of a literature study and own research on the problem, as a possibility of beginning further researches.

\section{Sources (selected)}

1. Borecki M. i Kwaśniewski M.: Metody analityczne obliczania ciśnienia deformacyjnego oraz przemieszczeń lepkosprężystego górotworu izotropowego $\mathrm{w}$ sąsiedztwie wyrobisk korytarzowych na dużych głębokościach. [Analytical methods for determining deformation stress and viscoelastic-isotropic rock mass displacement in the vicinity of headings at height depths] W: Metody i środki eksploatacji na dużych głębokościach. Wybrane zagadnienia. Wyd. PŚ, str. 195-221, Gliwice 1982

2. Biliński A.: Tąpania w świetle mechaniki górotworu odprężonego. ZN AGH, Kraków 1985.

3. Biliński A.: Ocena zagrożenia tąpnięciem wyrobiska eksploatacyjnego. GIG, Katowice 1992. 
4. Chudek M.: Zachowanie się skał stropowych nad wyrobiskiem ścianowym w świetle badań modelowych. ZN PŚ, Seria: Górnictwo, Zeszyt nr 30, Gliwice 1968

5. Chudek M. Mechanika górotworu. [Rock Mechanics]. Skrypt centralny wyższych studiów technicznych dla pracujących nr 956/61, Gliwice 1981

6. Chudek M. i Stefański L.: Wpływ postępu frontu górniczego na szybkość deformacji terenu na powierzchni. ZN PŚ, Seria:. Górnictwo, z. 145, Gliwice 1990

7. Chudek M., Strzałkowski P. i Ścigała R.: Przykład analizy wpływu prędkości postępu frontu eksploatacyjnego na przebieg deformacji na powierzchni terenu. The exemplary analysis of face advance speed influence on the land surface deformation process. Górnictwo i Geoinżynieria, Rok 31, Zeszyt 3/1, 2007

8. Dubiński J. i Konopko W.: Tąpania. Ocena. Prognoza. Zwalczanie. GIG, Katowice 2000

9. Drzewiecki J.: Wpływ postępu frontu ściany na dynamikę niszczenia górotworu karbońskiego. PN GIG, Nr 860, Katowice 2004

10. Filcek H., Kleczek Z. i Zorychta A.: Poglądy i rozwiązania dotyczące tąpań w kopalniach węgla kamiennego. ZN AGH, s. Górnictwo, nr 123, Kraków 1984

11. Filcek H., Walaszczyk J. i Tajduś A. Metody komputerowe w geomechanice górniczej. Śląskie Wydawnictwo Techniczne, Katowice 1994

12. Główny Instytut Górnictwa: Systemy Eksploatacji Węgla Kamiennego. Monografia polskiego górnictwa węglowego. Wydawnictwo „Śląsk”, Katowice 1968

13. Goszcz A.: Wybrane problemy zagrożenia sejsmicznego i zagrożenia tạpaniami w kopalniach podziemnych. Biblioteka Szkoły Eksploatacji Podziemnej. Seria z Lampką Górniczą, nr 21, Wydawnictwo Nauka - Technika, Kraków 2004

14. Griggs D.T. and Handin J.: Observations on fracture and a hypothesis of earthquakes. In: Rock Deformation, Mem. Geol. Soc. Am., 79, Griggs D.T. and Handin J. Eds, pp. 347-364, Geol. Soc. Am., New York 1960

15. Hoek E. and Brown E.T.: Underground Excavations in Rock. Institution of Mining and Metallurgy, London 1980

16. Itasca Consulting Group. FLAC2D - Fast Lagrangian Analysis of Continua in 2 Dimensions. User's Manuals, three volumes, Minneapolis, Minnesota. Itasca 19972017

17. Kłeczek Z.: Geomechanika górnicza. Wydawnictwo Śląsk, Katowice 1994

18. Kleczek Z.: Zagrożenie tąpaniami w polskich kopalniach węgla kamiennego i rud miedzi. Rockbursts hazard in Polish hard coal and copper mines. Warsztaty: Zagrożenia Naturalne w Górnictwie 2006, Mat. Symp., str. 143-155, 2006

19. Knothe S.: Prognozowanie wpływów eksploatacji górniczej. Wydawnictwo „Śląsk”, Katowice 1984

20. Knothe S.: Wpływ czasu na przebieg przemieszczeń, deformacji górotworu i powierzchni terenu wywołanych eksploatacją górniczą. W monografii: Ochrona powierzchni przed szkodami górniczymi, cz. 1, s. 324-330. Praca zbiorowa, Wydawnictwo "Śląsk", Katowice 1980

221. Konopko W., Patyńska R. i Makówka J.: Postęp, długość i wysokość ścian a zagrożenie tąpaniami. PN GIG Nr 809, Katowice 1995

22. Kwaśniewski M.: Badania nad mechanicznymi własnościami skał karbońskich dla potrzeb projektowania wyrobisk górniczych oraz prognozowania deformacyjnych i dynamicznych przejawów ciśnienia górotworu. W: "Metody 
i środki eksploatacji na dużych głębokościach. Wybrane zagadnienia.” Proj. Resort. Min. Górn. i Energ. Nr 119 (1981-1985), Politechnika Śląska, Wydział Górniczy, Instytut Projektowania, Budowy Kopalń i Ochrony Powierzchni, str. 63-72, Gliwice 1987

23. Kwaśniewski M. i Wang J.-A. Symulacja komputerowa eksploatacji pokładu węgla systemem ścianowym z zawałem stropu. ZN PŚ, Seria: Górnictwo, nr 1256, Gliwice 1994a

24. Kwaśniewski M. i Wang J.-A. Modelowanie numeryczne i badanie zachowania się górotworu w sąsiedztwie wyrobiska ścianowego 1003 w pokładzie 352 w KWK "Staszic". W monografii: Przodki ścianowe o wysokiej koncentracji produkcji, s. 117-175. Praca zbiorowa, Wyd. PŚ, Katowice - Gliwice 1994b

25. Kwaśniewski M.A. and Wang J.A.: 3D numerical modeling and study of mine tremors induced by coal mining in the vicinity of major faults - A case study. In FLAC and Numerical Modeling in Geomechanics (Ch.Detournay and R.Hart Eds.), pp. 379-388, Balkema, Rotterdam 1999

26. Ochrona powierzchni przed szkodami górniczymi. [Land Surface Protection Against Mining-Inducted Damages]. Praca zbiorowa, red. M. Borecki, Wydawnictwo „Śląsk”, Katowice 1980

27. Sałustowicz A.: Mechanika Górotworu. [Rock Mechanics]. Wydawnictwo Górniczo-Hutnicze, Katowice 1955

28. Singh R.D.: Principles and practices of modern coal mining. New Age Int. (P) Ltd. Publ., Balkema, Netherlands 1985

29. Strzałkowski P.: New mathematical model for description of time-dependent surface subsidence. In: Transactions of the Institution of Mining and Metallurgy, Section A: Mining Technology, 110(3), pp.178-182, 2001

30. Strzałkowski P.: Prognozowanie wpływu prędkości postępu frontu wybierania na przebieg deformacji w czasie. Predicting of influence of face advance speed on mining subsidence rate. ZN PŚ, Seria: Górnictwo, z. 283, Gliwice 2008

31. Strzałkowski P.: Zarys ochrony terenów górniczych. Wyd. PŚ, Gliwice 2010

32. Strzalkowski P.: Prognozowanie czasu trwania końcowej fazy poeksploatacyjnych ruchów terenu górniczego. Prediction of deformations in the transient state with regard to the duration of the final phase of mining area movements. Przegląd Górniczy, t. 70, 2014

33. Strzałkowski P. i Maruszczyk M.: Prognozowanie deformacji górotworu z uwzględnieniem zmiennej czasowej. Predicting of rock mass deformation over time. Górnictwo i Geologia, z.5, t.2, Gliwice 2010

34. Ścigala R.: Komputerowa symulacja postępu frontu w zastosowaniu do oceny prognozowanych deformacji powierzchni terenu. Computer simulation of rate of front advance applicated for evaluation of area surface forecast deformation. Przegląd Górniczy, nr 5, Katowice 2003

35. Ścigała R.: Identyfikacja współczynnika prędkości osiadania z uzwględnieniem czasoprzestrzennego rozwoju niecki obniżeniowej. Identification of subsidence velocity coefficient taking into consideration temporary-spatial development of subsidence though. Przegląd Górniczy, t. 65, nr 11/12, 2009

36. Ścigała R.: Kompleksowa identyfikacja współczynnika prędkości osiadania dla warunków jednej z kopalń GZW. A comprehensive identification of subsidence 
rate coefficient for one of Upper Silesian coal mines conditions. Górnictwo i Geologia, t.7, z.1, str. 1999-210, 2012

37. Tomiczek K.: Modelowanie numeryczne i badanie wpływu prędkości eksploatacji na deformacje górotworu i powierzchni terenu. Numerical modelling and research on the influence of mining face advance on the on rock mass and strata deformation. Praca magisterska, Politechnika Śląska, Wydział Górnictwa i Geologii, Gliwice 1995.

38. Tomiczek K.: Krótka numeryczna analiza wpływu prędkości eksploatacji na deformacje górotworu i powierzchni terenu. Short numerical analysis of the influence of the face advance of mining exploitation on the surface and strata deformations. Zeszyty Naukowe Politechnika Śląska nr 1751 Górnictwo; z. 276) Gliwice, Wydaw. PŚ, s. 193-207, 2007

39. Tomiczek K.: Krótka numeryczna analiza wpływu prędkości postępu frontu ścianowego na wzrost zagrożenia wstrząsami podziemnymi. Short numerical analysis of the influence of the face advance rate on the hazard increase of underground tremors W: Geotechnika - Geotechnics 2008. XIII Międz. Symp. Gliwice - Ustroń 1417.10.2008r., Materiały nauk. cz.1: polska, Wydz. Górnictwa i Geologii, Katedra Geomechaniki, Budownictwa Podziemnego i Zarządzania Ochroną Powierzchni, s.439-452, 2008

40. Tomiczek K. (praca wstrzymana $\mathrm{z}$ powodów finansowych): Wpływ nieciągłości na wzrost zagrożenia tąpaniami w rejonie prowadzonych robót eksploatacyjnych. Cz. II. Badanie wpływu prędkości eksploatacji prowadzonej w strefie przyuskokowej na rozkład pola naprężeń i przemieszczeń w sąsiedztwie uskoku. Influence of discontinuities on the increase of rockburst risk in the vicinity of underground mining. Vol. II. Research on the influence of face advance rate in the vicinity of the fault zone on the distribution of stresses and displacements. Gliwice 2010

41. Walaszczyk J., Barnat A., Hachaj S., Bystrowski J. i Toś W.: Zastosowanie informatyki w geomechanice - Materiały do ćwiczeń projektowych. The use of computer science in geomechanics - Materials for project courses. Skrypt uczelniany AGH nr 1355, Kraków 1993

42. Wesolowski M.: Możliwości stosowania modeli numerycznych do opisu deformacji powierzchni terenu górniczego. Possibilities of applying numerical models for the description of deformation of the mining area surface. Przegląd Górniczy, nr 4/2014, 2014

43. Zych J., Drzęźla B. i Strzałkowski P. Prognozowanie deformacji powierzchni terenu pod wpływem eksploatacji górniczej. Skrypt uczelniany PŚ nr 1684, Gliwice 1994

44. Zych J.: Metoda prognozowania wpływów eksploatacji górniczej na powierzchnię terenu uwzględniająca asymetryczny przebieg procesu deformacji, ZN PŚ, Seria: Górnictwo, z. 220, Gliwice 1987 